\title{
The effect of zinc fertilization on the yield and element content of ryegrass
}

\author{
Rita Kremper - László Seres \\ Department of Agricultural Chemistry and Soil Science, \\ University of Debrecen, \\ 4032 Debrecen Böszörményi út 138. Hungary, \\ E-mail:kremper@agr.unideb.hu
}

Keywords: zinc, fertilization, greenhouse

\begin{abstract}
The effect of Zn fertilization on the yield and $\mathrm{Zn}, \mathrm{N}, \mathrm{P}, \mathrm{K}, \mathrm{Mg}$ and Mn content of ryegrass was studied in a greenhouse experiment for 8 chernozem soils with three replicates under uniform NPK supply and irrigation. The applied Zn rates were 0, 2.5 and 5 mg/kg Zn.Due to Zn doses the yield incrased significantly. Zn fertilization increased the plant $Z n$ content and decreased the plant $P$ and Mn content significantly. For $N$, Kand $M g$ there was no significant effect.
\end{abstract}

\section{INTRODUCTION}

The appropriate nutrient supply is one of the most important factor of the success for intensive plant production. Beside the three most important macroelement (NPK) fertilization, the micronutrient replacement is also of great importance.

In Hungary $40-45 \%$ of agricultural areas is $\mathrm{Zn}$ deficient (Elek et al., 1984), thus it is reasonable to supply NPK fertilizers with $\mathrm{Zn}$, especially for those cultures that are sensitive to $\mathrm{Zn}$ deficiency (e.g. maize). The most important soil factor associated with zinc deficiency is $\mathrm{pH}$, as $\mathrm{Zn}$ availability is markedly reduced with increasing soil $\mathrm{pH}$. Other soil factors affecting $\mathrm{Zn}$ availability are high available phosphorous, low total $\mathrm{Zn}$ status , high humus content and other nutrient deficiencies (Armour et al., 1993).

Chernozem soils in Hungary have adequate total $\mathrm{Zn}$ content, however intensive phosphorus fertilization can cause zinc deficiency. Csathó et al. (2009) observed zinc deficiency in chernozem soil over $150 \mathrm{~kg} / \mathrm{ha} \mathrm{P}_{2} \mathrm{O}_{5}$ dose for maize. In accordance with it Kincses et al. (2005) experienced decrease in zinc content for maize and wheat by $140 \mathrm{mg} / \mathrm{kg} \mathrm{P}_{2} \mathrm{O}_{5}$ dose in case of chalcareous chernozem soil. High $\mathrm{pH}$ can also occur on cherozem soils as a result of large lime content.

In our paper we studied the Zn supply of chernozem soils. Balla et al. (2005) observed yield increase for 10 $\mathrm{mg} / \mathrm{kg} \mathrm{Zn} \mathrm{dose} \mathrm{on} \mathrm{calcareous} \mathrm{chernozem} \mathrm{soil} \mathrm{under} \mathrm{greenhouse} \mathrm{circumstances.} \mathrm{Now} \mathrm{we} \mathrm{extend} \mathrm{the} \mathrm{examination}$ for eight different chernozem soil samples. The soil samples were collected from Hajdú-Bihar County in Hungary. In a greenhouse experiment we examined the effect of zinc fertilization on the yield and on the element content ( $\mathrm{Zn}, \mathrm{P}, \mathrm{N}, \mathrm{K}, \mathrm{Mg}$ and $\mathrm{Mn}$ ) of ryegrass.

\section{MATERIALS AND METHODS}

A pot experiment was conducted using 8 chernozem arable soils. Pots were filled with $2250 \mathrm{~g}$ air dry soils. The treatments included NPK application, NPK $+2.5 \mathrm{mg} / \mathrm{kg} \mathrm{Zn}$ and NPK $+5 \mathrm{mg} / \mathrm{kg} \mathrm{Zn}$ levels with three replicates.

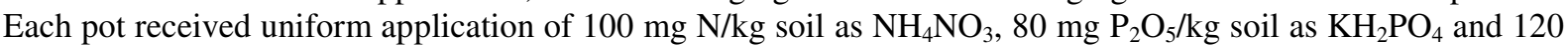
$\mathrm{mg} \mathrm{K} 2 \mathrm{O} / \mathrm{kg}$ soil as $\mathrm{KH}_{2} \mathrm{PO}_{4}$ and $\mathrm{KCl}$. The zinc was applied as $\mathrm{ZnSO}_{4} \cdot 7 \mathrm{H}_{2} \mathrm{O}$ solution. Soils were kept at constant moisture by daily irrigation, which was $75 \%$ of maximum water capacity of the soils. The experimental plant was ryegrass (Lolium perenne L.). $1.7 \mathrm{~g}$ seeds were sown in the soils per pots. After the first (33 day) and second (53 day) harvest $100 \mathrm{mg} / \mathrm{kg} \mathrm{N}$ was added to the pots as $\mathrm{NH}_{4} \mathrm{NO}_{3}$ solution.

For the initial soils total-N, phosphate, potassium and $\mathrm{pH}$ values were measured from 0.01 molar $\mathrm{CaCl}_{2}$ soil extract that was prepared according to Houba et al. (1990). The total-N and phosphate content were measured with SKALAR Continuous Flow Analyzer. Calcium and magnesium content was determined from ammonium-lactate soil extract. The $\mathrm{Zn}$ content was measured from $\mathrm{CaCl}_{2}$-DTPA solutions. The most important soil properties for the initial soils are summarised in Table 1.

The plants' zinc, phosphorus, nitrogen, potassium, magnesium and manganese - contents were analysed as follows:

The plant samples from the first cut were digested with cc. $\mathrm{H}_{2} \mathrm{SO}_{4}-\mathrm{cc} . \mathrm{H}_{2} \mathrm{O}_{2}$. and cc. $\mathrm{HNO}_{3}$-cc. $\mathrm{H}_{2} \mathrm{O}_{2}$. 
Zinc, manganese and magnesium content were measured from nitric acid digestion by AAS technique (Varian Spectr. AA-20). Potassium content was measured from sulphuric acid digestion with flame photometer (UNICAM SP95B). The phosphorus content was determined from the sulphuric acid digestion with vanadateyellow spectrophotometric method. The total nitrogen was determined with CNS element analyser. The data were evaluated with two variable variance analysis.

Table 1 Main soil characteristics of the initial soil samples.

\begin{tabular}{|c|c|c|c|c|c|c|c|c|c|c|}
\hline Nr. & Soil Type & $* \mathrm{~K}_{\mathrm{A}}$ & $\mathrm{Hu} \%$ & $\mathrm{pH}_{\mathrm{CaCl} 2}$ & $\begin{array}{l}\text { Total N } \\
\mathrm{mg} / \mathrm{kg}\end{array}$ & $\begin{array}{l}\mathrm{PO}_{4}{ }^{3-} \\
\mathrm{mg} / \mathrm{kg}\end{array}$ & $\begin{array}{l}\mathrm{K} \\
\mathrm{mg} / \mathrm{kg}\end{array}$ & $\begin{array}{l}\mathrm{AL}-\mathrm{Ca} \\
\mathrm{mg} / \mathrm{kg}\end{array}$ & $\begin{array}{l}\text { AL-Mg } \\
\mathrm{mg} / \mathrm{kg}\end{array}$ & $\begin{array}{r}\mathrm{Zn} \\
\mathrm{DTPA} \\
\mathrm{mg} / \mathrm{kg} \\
\end{array}$ \\
\hline 1 & $\begin{array}{l}\text { Leached } \\
\text { chernozem }\end{array}$ & 43 & 2.7 & 5.86 & 17.5 & 1.78 & 51.6 & 8180 & 559.4 & 1.9 \\
\hline 2 & $\begin{array}{l}\text { Meadow } \\
\text { chernozem }\end{array}$ & 45 & 3.2 & 7.29 & 68.6 & 0.86 & 47.0 & 8960 & 1018.3 & 0.9 \\
\hline 3 & $\begin{array}{l}\text { Meadow } \\
\text { chernozem }\end{array}$ & 42 & 2.7 & 7.21 & 53.4 & 0.97 & 56.3 & 12060 & 284.4 & 0.6 \\
\hline 4 & $\begin{array}{l}\text { Meadow } \\
\text { chernozem }\end{array}$ & 46 & 2.7 & 7.40 & 30.8 & 1.16 & 65.8 & 23189 & 564.1 & 1.1 \\
\hline 5 & $\begin{array}{l}\text { Meadow } \\
\text { chernozem }\end{array}$ & 42 & 2.1 & 7.45 & 45.4 & 1.06 & 83.2 & 13170 & 419.4 & 1.3 \\
\hline 6 & $\begin{array}{l}\text { Calcareous } \\
\text { chernozem }\end{array}$ & 42 & 2.8 & 7.45 & 36.4 & 0.74 & 35.8 & 10940 & 703.0 & 0.6 \\
\hline 7 & $\begin{array}{l}\text { Meadow } \\
\text { chernozem }\end{array}$ & 43 & 3.1 & 7.36 & 29.7 & 1.17 & 53.9 & 7660 & 609.5 & 2.3 \\
\hline 8 & $\begin{array}{l}\text { Calcareous } \\
\text { chernozem }\end{array}$ & 43 & 3.0 & 7.18 & 58.9 & 1.03 & 187.3 & 1164 & 129.7 & 2.2 \\
\hline
\end{tabular}

* $\mathrm{K}_{\mathrm{A}}$ is the water amount taken up by soil to plasticity capacity $\left(\mathrm{cm}^{3} / 100 \mathrm{~g}\right.$ soil)

\section{RESULTS AND DISCUSSION}

The average dry matter production ryegrass at the first cut is summarized in Table 2. Significant positive relationship was found between $\mathrm{Zn}$ application and the dry matter production. Between the soils and dry production there was also significant relationship.

Based on the data of Table 1 and Table 2 the positive effect of $\mathrm{Zn}$ fertilization is characteristic even for those soils with high $\mathrm{Zn}$ content.

Table 2 Mean dry weight of ryegrass at the $1^{\text {st }}$ cut

\begin{tabular}{|l|r|r|r|r|r|r|}
\hline \multirow{3}{*}{ Soil sample } & \multicolumn{2}{|l|}{ Mean dry weight (g/ pot) } & \multirow{2}{*}{ mean } & \multicolumn{2}{l|}{$\begin{array}{l}\text { Difference between } \\
\text { treatments in dry weight }\end{array}$} \\
\cline { 2 - 4 } & \multicolumn{3}{|l|}{ Zn doses (mg /kg soil) } & & & $5-0$ \\
\cline { 2 - 7 } & 0 & 2.50 & 5.00 & & $2.5-0$ & 0.30 \\
\hline 1 & 3.70 & 4.00 & 4.73 & 4.14 & 0.40 & 1.03 \\
\hline 2 & 4.00 & 4.40 & 5.03 & 4.48 & 0.93 & 1.30 \\
\hline 3 & 3.03 & 3.97 & 4.33 & 3.78 & 0.77 & 0.83 \\
\hline 4 & 3.33 & 4.10 & 4.17 & 3.87 & 0.63 & 0.43 \\
\hline 5 & 5.43 & 6.07 & 5.87 & 5.79 & -0.33 & 0.50 \\
\hline 6 & 2.83 & 2.50 & 3.33 & 2.89 & 0.50 & 0.80 \\
\hline 7 & 4.60 & 5.10 & 5.40 & 5.03 & 0.27 & -0.07 \\
\hline 8 & 4.80 & 5.07 & 4.73 & 4.87 & 1.07 & 2.10 \\
\hline mean & 3.34 & 3.89 & 4.40 & 3.88 & & \\
\hline
\end{tabular}

$\mathrm{SD}_{5 \%}$ between $\mathrm{Zn}$ treatments $=0.25$

$\mathrm{SD}_{5 \%}$ between soils $=0.41$

$\mathrm{SD}_{5 \%}$ between any two combinations $=0.71$ 
The results of variance analysis for the plant $\mathrm{Zn}$ content are represented in Table 3. The significant effect of $\mathrm{Zn}$ fertilization on the $\mathrm{Zn}$ content of the plants is manifested. The zinc content increment for the $2.5 \mathrm{mg} / \mathrm{kg}$ zinc treatment ranges from $1.94 \mathrm{mg} / \mathrm{kg}$ to $13.62 \mathrm{mg} / \mathrm{kg}$. For sample 1 and 8 the increments were relatively small. These soils are less zinc deficient, that is indicated with the soil dissolved zinc content by DTPA, which was relatively high.

For sample 7 in spite of the high dissolved zinc content from the soil $(2.32 \mathrm{mg} / \mathrm{kg})$, the zinc content and the dry matter of plant increased markedly for zinc treatment. It can be explained with the high $\mathrm{pH}(\mathrm{pH}=7.36)$ and high phosphate content $(1.17 \mathrm{mg} / \mathrm{kg})$ of the soil. Further zinc content increment can be observed for the $5 \mathrm{mg} / \mathrm{kg}$ zinc treatment. Though the degree of the enhancement was less in most of the cases.

Table 3 Mean $\mathrm{Zn}$ content of ryegrass, 1st cut

\begin{tabular}{|l|r|r|r|r|r|r|}
\hline \multirow{3}{*}{ soil sample } & \multicolumn{2}{|l|}{ Zn content of plant $(\mathrm{mg} / \mathrm{kg})$} & \multirow{2}{*}{$\begin{array}{l}\text { Difference between } \\
\text { treatments in dry weight }\end{array}$} \\
\cline { 2 - 4 } & \multicolumn{3}{|l|}{ Zn doses (mg/ kg soil) } & & & \\
\cline { 2 - 7 } & 0 & 2.5 & 5 & & $2.5-0$ & $5-0$ \\
\hline 1 & 44.4 & 46.4 & 49.1 & 46.6 & 2.0 & 4.8 \\
\hline 2 & 26.9 & 39.6 & 46.7 & 37.7 & 12.7 & 19.7 \\
\hline 3 & 25.8 & 39.4 & 45.7 & 37.0 & 13.6 & 19.9 \\
\hline 4 & 31.9 & 42.6 & 43.0 & 39.2 & 10.7 & 11.1 \\
\hline 5 & 27.4 & 39.7 & 48.9 & 38.7 & 12.4 & 21.6 \\
\hline 6 & 15.2 & 25.2 & 31.4 & 23.9 & 10.0 & 16.2 \\
\hline 7 & 25.3 & 37.4 & 43.7 & 35.5 & 12.1 & 18.4 \\
\hline 8 & 41.2 & 43.1 & 48.0 & 44.1 & 1.9 & 6.8 \\
\hline mean & 29.8 & 39.2 & 44.6 & 37.8 & 9.4 & 5.4 \\
\hline
\end{tabular}

$\mathrm{SD}_{5 \%}$ between $\mathrm{Zn}$ treatments $=3.73$

$\mathrm{SD}_{5 \%}$ between soils $=2.28$

$\mathrm{SD}_{5 \%}$ between any two combinations $=6.48$

In Table 4 the plants' $\mathrm{P}$ content can be seen in $(\mathrm{mg} / \mathrm{g})$. In case of control treatments it ranges from 3.0 to 5.3. All soils (the control soils as well) got $\left(100 \mathrm{mg} \mathrm{P}_{2} \mathrm{O}_{5}\right) / \mathrm{kg}$ soil fertilization, but the initial $\mathrm{P}$ status of the soil is somewhat reflected by the results. For example on soil sample 6 and sample 2 grew the plants with the lowest $\mathrm{P}$ content. Accordingly the dissolved P content was the smallest for these soils in the initial state.

It can be stated from the results that the zinc fertilization decreased the plant phosphorous content significantly.

In case of $2.5 \mathrm{mg} / \mathrm{kg}$ zinc treatment this negative effect can be observed for four soils, and in case of $5 \mathrm{mg} / \mathrm{kg}$ zinc treatment for six soils. It is well documented from the literature that there is antagonism between phosphorous and zinc (Gartel,1969). The antagonism was reported in case of phosphorous fertilization, when the overdose of phosphorous caused the lack of zinc. Our results show that even zinc, as a microelement can decrease the phosphorous content of plant. Zinc and phosphorus form precipitate in soil, which is one of the reason for the antagonism of these elements. However the antagonism has mainly plant physiological explanation (Stukenholz, 1965). The decrease in P content of the plants was averagely $24 \%$ for $5 \mathrm{mg} / \mathrm{kg} \mathrm{Zn}$ fertilization. 
Table 4 Mean P content of ryegrass, 1st cut

\begin{tabular}{|l|r|r|r|r|r|r|}
\hline \multirow{3}{*}{ Soil sample } & \multicolumn{4}{|c|}{ P content of plant (mg/g) } & \multirow{2}{*}{ mean } & \multicolumn{2}{l|}{$\begin{array}{l}\text { Difference between } \\
\text { treatments in P content }\end{array}$} \\
\cline { 2 - 4 } & \multicolumn{2}{|c|}{ Zn doses (mg/ kg soil) } & & & \\
\cline { 2 - 7 } & 0 & 2.5 & 5 & & $2.5-0$ & $5-0$ \\
\hline 1 & 4.9 & 4.2 & 3.8 & 4.3 & -0.7 & -1.1 \\
\hline 2 & 3.1 & 2.9 & 2.6 & 2.8 & -0.2 & -0.5 \\
\hline 3 & 4.0 & 3.9 & 3.5 & 3.8 & -0.1 & -0.5 \\
\hline 4 & 4.2 & 3.8 & 3.3 & 3.8 & -0.4 & -0.8 \\
\hline 5 & 3.9 & 3.9 & 3.9 & 3.9 & 0.0 & 0.0 \\
\hline 6 & 3.0 & 3.0 & 2.2 & 2.7 & 0.0 & -0.8 \\
\hline 7 & 5.3 & 4.8 & 4.8 & 5.0 & -0.5 & -0.5 \\
\hline 8 & 6.7 & 6.5 & 6.7 & 6.6 & -0.2 & 0.0 \\
\hline mean & 4.4 & 4.1 & 3.9 & 4.1 & -0.3 & -0.2 \\
\hline
\end{tabular}

$\mathrm{SD}_{5 \%}$ between $\mathrm{Zn}$ treatments $=0.24$

$\mathrm{SD}_{5 \%}$ between soils $=0.39$

$\mathrm{SD}_{5 \%}$ between any two combinations $=0.68$

Table 5 shows the Mn content of the ryegrass. The Mn content varies between 38.7 and $90.3 \mathrm{mg} / \mathrm{kg}$. Most of the cases the Mn content decreased significantly as a cause of zinc fertilization. Manganese and zinc have competition interactions, the increased zinc content of the soil inhibited the plant manganese uptake.

Table 5. Mean Mn content of ryegrass, 1st cut

\begin{tabular}{|l|r|r|r|r|r|r|}
\hline \multirow{3}{*}{ soil sample } & \multicolumn{4}{|c|}{ Mn content of plant (mg/kg) } & \multirow{2}{*}{$\begin{array}{l}\text { Difference between } \\
\text { treatments in Mn content }\end{array}$} \\
\cline { 2 - 4 } & \multicolumn{3}{|l|}{ Zn doses (mg/ kg soil) } & & & \\
\cline { 2 - 7 } & 0 & 2.5 & 5 & & $2.5-0$ & $5-0$ \\
\hline 1 & 51.3 & 45.7 & 38.7 & 45.2 & -5.7 & -12.7 \\
\hline 2 & 72.3 & 73.7 & 65.3 & 70.4 & 1.3 & -7.0 \\
\hline 3 & 90.3 & 81.3 & 76.0 & 82.6 & -9.0 & -14.3 \\
\hline 4 & 57.3 & 62.3 & 52.3 & 57.3 & 5.0 & -5.0 \\
\hline 5 & 64.0 & 62.3 & 67.3 & 64.6 & -1.7 & 3.3 \\
\hline 6 & 50.3 & 44.3 & 47.0 & 47.2 & -6.0 & -3.3 \\
\hline 7 & 63.4 & 54.3 & 58.7 & 58.8 & -9.0 & -4.7 \\
\hline 8 & 56.3 & 50.3 & 53.0 & 53.2 & -6.0 & -3.3 \\
\hline mean & 63.2 & 59.3 & 57.3 & 59.9 & -3.9 & -5.9 \\
\hline
\end{tabular}

$\mathrm{SD}_{5 \%}$ between $\mathrm{Zn}$ treatments $=4.5$

$\mathrm{SD}_{5 \%}$ between soils $=7.6$

$\mathrm{SD}_{5 \%}$ between any two combinations $=13.1$

There were not significant effects of zinc fertilization on nitrogen, potassium and magnesium content of the plants. The nitrogen content of the dry matter ranged from 3.6 to $4.2 \%$. Potassium content varied from 5.3 to $10.2 \%$, and magnesium from 0.26 to $0.32 \%$. 


\section{CONCLUSIONS}

In our paper we studied the effects of zinc fertilization on the yield of ryegrass under greenhouse circumstances for eight chernozem soils. It can be stated that the zinc fertilization increased the yield, however ryegrass is not sensitive to zinc deficiency. It draws attention to the fact that zinc fertilization can be reasonable in chernozem soils, especially for zinc demanding cultures such as maize.

We also investigated how zinc fertilization influence the uptake of several elements. These are zinc, potassium, magnesium, nitrogen, phosphorous and manganese. We concluded that zinc fertilization increased the zinc content of plants. The increment was more than $30 \%$ in most of the cases for $2.5 \mathrm{mg} / \mathrm{kg}$ zinc dose. The zinc fertilization decreased phosphorus and manganese content of the plants. The decrease in $\mathrm{P}$ content of the plants was in average $24 \%$ for $5 \mathrm{mg} / \mathrm{kg} \mathrm{Zn}$ fertilization. The decrease in Mn content of the plants in average $9 \%$.

We did not find significant interactions between zinc fertilization and the potassium, nitrogen and magnesium content of plants.

\section{REFERENCES}

Armour J.D. and Brennan R.F. (1993) Zinc in Soil Analysis an Interpretational Manual Commisioned by ASPAC CSIRO publishing p. 281285.

Balláné Kovács A, Berényi S., Vágó I., (2005): Comparison of $0.01 \mathrm{M} \mathrm{CaCl}_{2}-0,005 \mathrm{M}$ DTPA and 0.1M KCl-0.01M EDTA extractants for determination of $\mathrm{Cu}$ and $\mathrm{Zn}$ in soils in greenhouse experiment Réz, cink a környezetben, Mosonmagyaróvár, Acta Agronomica Óváriensis Vol. 47. num.1. 37.-47. ISSN: 1416-647x

Csathó P.,Árendás T. (2009 ): A foszfor indukálta cinkhiány orvoslása levéltrágyázással .Agrofórum Extra 27 kukoricatermesztőknek $60 .-64$.

Elek É-Patócs I (1984): A magyarországi I. talajvizsgálati ciklus eredményeinek értékelése. MÉM NAK Kiadványa. Budapest.

Gärtel, W. (1969).: Die Phosphattüberdüngung im Weinbau - EA.= LUFA -Tagung, Würzburg

Houba, V.J.G., Novozamsky, L., Lexmond, T. M. and Van der Lee, J.J. (1990): Applicability of 0,01 $\mathrm{M} \mathrm{CaCl}_{2}$ as a single extraction solution for the assessment of the nutrient status of soils and other diagnostic purposes. Commun. Soil Sci. Plant Anal. 21. 2281-2290.

Kincses, S.-né, Nagy P. T. Balláné, K.A., Filep T. (2005) Az NPK trágyázás hatása a búza (Triticum aestivum) és a kukorica (Zea mays) Zn felvételére. Réz cink a környezetben Mosonmagyaróvár, 47, 239.-253.

Stukenholtz, D.Dogan, G., Olson, R.A. (1965): On the mechanism of phosphorus - zinc interaction in corn nutrition. Proc. Soil. Sci. Soc. Amer. 30, 759 